\title{
Long-term Effect of Split Iron Dextran/Hemoglobin Supplementation on Erythrocyte and Iron Status, Growth Performance, Carcass Parameters, and Meat Quality of Polish Large White and 990 Line Pigs
}

\author{
Mateusz Szudzik ${ }^{1} \cdot$ Paweł Lipiński ${ }^{1} \cdot$ Aneta Jończy $^{1} \cdot$ Rafał Mazgaj $^{1} \cdot$ Marek Pieszka $^{2} \cdot$ Marian Kamyczek $^{3}$. \\ Ewa Smuda $^{1} \cdot$ Rafał R. Starzyński $^{1}$
}

Received: 15 August 2019 / Accepted: 22 October 2019 /Published online: 8 November 2019

(C) The Author(s) 2019

\begin{abstract}
Heme is an efficient dietary iron supplement applied in humans and animals to prevent iron deficiency anemia (IDA). We have recently reported that the use of bovine hemoglobin as a dietary source of heme iron efficiently counteracts the development of IDA in young piglets, which is the common problem in pig industry. Here, we used maternal Polish Large White and terminal sire breed (L990) pigs differing in traits for meat production to evaluate the long-term effect of split supplementation with intramuscularly administered small amount of iron dextran and orally given hemoglobin on hematological indices, iron status, growth performance, slaughter traits, and meat quality at the end of fattening. Results of our study show that in pigs of both breeds split supplementation was effective in maintaining physiological values of RBC and blood plasma iron parameters as well as growth performance, carcass parameters, and meat quality traits. Our results prove the effectiveness of split iron supplementation of piglets in a far-reach perspective.
\end{abstract}

Keywords Heme $\cdot$ Iron deficiency anemia $\cdot$ Pig $\cdot$ Supplementation $\cdot$ Slaughter performance $\cdot$ Meat quality

\section{Introduction}

Early postnatal iron deficiency anemia (IDA) is a widespread pathology in livestock affecting especially suckling piglets [1, 2]. The common cause of iron deficiency in newborn piglets is a striking imbalance between high iron demand and inadequate iron supply. Huge iron requirements during the first few weeks after birth (7-16 mg Fe/piglet/day) [2, 3] result from the selection of piglets for a large litter size, high birth weight, rapid growth and in consequence greater blood volume, and increased red blood cells (RBC) count. Considering that $\mathrm{RBC}$ are the largest reservoir of iron in the body [2], meeting iron requirements for erythropoiesis from natural

Rafał R. Starzyński

r.starzynski@ighz.pl

1 Department of Molecular Biology, Institute of Genetics and Animal Breeding PAS, ul. Postępu 36a, 05-552 Magdalenka, Jastrzębiec, Poland

2 Department of Animal Nutrition \& Feed Science, National Research Institute of Animal Production, Kraków, Poland

3 Pig Hybridization Centre, National Research Institute of Animal Production, Pawłowice, Poland iron-deficient sources such as hepatic iron stores [2, 4] and sow's milk [5, 6] is unreachable in suckling piglets [7]. Without iron supplementation piglets regularly become anemic within 2 weeks postpartum [2].

Intramuscular administration of large amount of iron dextran (FeDex) on days 3 to 6 postpartum is current practice in the swine industry, rectifying the hematological status of piglets [8-11]. However, routinely applied dose of $200 \mathrm{mg}$ Fe per piglet in the form of a single intramuscular injection of FeDex seems not being efficiently metabolized and detoxified [8]. Moreover, we have previously reported that high iron parenteral supplementation with FeDex induces expression of hepcidin (Hepc) [8, 12, 13], a 25-amino acid peptide hormone, the master regulator of the systemic iron homeostasis in vertebrates [14]. It is well established that high Hepc may perturb body iron homeostasis by inhibiting both duodenal iron absorption and iron recycling by macrophages of the reticuloendothelial system (RES) that catabolize heme contained in phagocytosed senescent RBC [15]. In consequence of this two-way hepcidin-dependent regulation, availability of iron for erythropoiesis is strongly decreased.

To minimize both toxicity of supplemental iron and its capacity to induce hepcidin synthesis, we proposed several modifications of routine procedure of FeDex administration 
to piglets $[8,12]$. Furthermore, considering that heme preparations have been successfully used to prevent and treat IDA in humans [16-18], dogs [19], and pigs [20, 21], we used bovine hemoglobin as heme iron supplement. We showed that oral supplementation of piglets with hemoglobin rescues them from severe IDA observed in non-supplemented animals [22]. However, to strengthen the curative effect of dietary hemoglobin, we successfully used a split iron supplementation regime involving additional supportive injection of a small amount of FeDex on day 3 after birth. This modified procedure has been shown to better cover iron needs of 28 -day-old piglets, i.e., at the age of weaning [22]. Indeed, most studies dealing with iron supplementation procedures in piglets evaluate their efficacy in animals during the period from birth to weaning $[1,2]$. However, a final, far-reaching goal of iron supplementary procedures in pig breeding is to assure a permanent and durable iron balance in pigs until slaughter. Therefore, in this study, we evaluated a long-term effect of split (FeDex/hemoglobin) iron supplementation on RBC status, iron content in tissues (including skeletal muscles), and its impact on growth performance, carcass parameters, and meat quality traits of 180-day-old (slaughter age) Polish Large White (PLW) and 990 line (L990) pigs. We used in our experiment these two Polish breeds considering their different characteristics of meat performance and distinct use in crossbreeding program in Poland [23]. In contrast to PLW, a typical maternal breed, L990 is exploited as a terminal sire breed [24]. Importantly, we compared our experimental supplementation with the procedure considered a gold standard in the therapy of IDA in pigs, involving intramuscular injection of high amount of iron in the form of FeDex.

We provide evidence that the experimental split iron supplementation of piglets, which is not fully effective at weaning, does not entail negative consequences for the maintenance of RBC indices, systemic iron status, growth performance, and meat quality of pigs at the end of fattening.

\section{Materials and Methods}

\section{Animals and Experimental Design}

Experiment was conducted at the Pig Hybridization Centre in Pawłowice (National Research Institute of Animal Production, Balice, Poland). The experimental procedures used in this study were in compliance with the EU guidelines for the care and handling of research animals (EU Directive 2010/63/EU for animal experiments). According to Polish legislation, tests on animals using feed additives and supplements (including iron supplements such as $\mathrm{FeSO}_{4}$, hemoglobin, dried erythrocytes, plasma, blood) are not considered research procedures and therefore do not interfere with animal welfare. Therefore, ethical permission is not required. A total of 28 Polish Large White (PLW) and 990 line (L990) piglets (males) born from 6 sires (3 PLW and 3 L990) and 8 dams (4 PLW and 4 L990) from different litters, housed in standard conditions $\left(70 \%\right.$ humidity and a temperature of $22{ }^{\circ} \mathrm{C}$ in cages with straw bedding), were used. Until weaning (day 28 after birth) sows were allowed to nurse their piglets and piglets had no access to the sows' feed. The Prestarter Wigor 1 Plus feed (containing $238 \mathrm{mg} \mathrm{Fe} / \mathrm{kg}$ as estimated by flame spectrometry) was offered to piglets from day 5 to day 45 after birth. Piglets from both breeds were allotted into the following 4 experimental groups ( 7 piglets per group) on the basis of balanced body weight at day 3 after birth: PLW and L990, piglets intramuscularly injected with $100 \mathrm{mg} \mathrm{Fe} / \mathrm{kg}$ b.w. in the form of iron dextran, FeDex (Ferran 100, Vet-Agro, Lublin, Poland) on day 3 after birth (supplementation routinely applied to piglets at the Pig Hybridization Centre in Pawłowice); PLW and L990, piglets intramuscularly injected with $40 \mathrm{mg} \mathrm{Fe} / \mathrm{kg}$ b.w in the form of FeDex on day 3 , and supplemented orally from day 3 to day 45 with bovine hemoglobin (Bovogen, East Keilor, Australia) added to the feed in the proportion $38 \mathrm{~g}$ hemoglobin per $1 \mathrm{~kg}$ of feed (split supplementation). The final total iron content in this mixture, assessed by flame atomic absorption spectroscopy was $612 \mathrm{mg} \mathrm{Fe} / \mathrm{kg}$. The mean daily consumption of feed per piglet and the respective calculated iron intake were monitored in the 4 experimental groups and did not differ significantly between animals (data not shown). After 45th day of life, piglets were fed with the following typical feeds offered to pigs during intensive fattening: starter (up to body weight $30 \mathrm{~kg}$ containing $150 \mathrm{mg} \mathrm{Fe} / \mathrm{kg}$ feed), grower (until body weight $70 \mathrm{~kg}$ containing $100 \mathrm{mg} \mathrm{Fe} / \mathrm{kg}$ feed), and finisher (until the day of slaughter containing $80 \mathrm{mg} \mathrm{Fe} / \mathrm{kg}$ feed).

After reaching the slaughter weight $-110 \mathrm{~kg}$ (on day $\sim 180$ after birth) - animals were transported to the slaughterhouse belonging to National Research Institute of Animal Production, Pig Hybridization Centre, and slaughtered by exsanguination after being electric stunned, then scalded, dehaired, eviscerated, and split down the midline according to commercial procedures.

\section{Biological Sample Collection}

Blood was drawn on day 28 after birth by venipuncture of the jugular vein (vena jugularis externa) and at slaughter using syringe with Li-Heparin (S-Monovette ${ }^{\circledR}$ with S-MonovetteNeedle () . The blood samples were centrifuged $(1200 \times g$, $10 \mathrm{~min}, 4^{\circ} \mathrm{C}$ ) to separate the plasma. Plasma samples were immediately aliquoted and stored at $-80^{\circ} \mathrm{C}$. Samples of the liver, spleen, kidney, heart, and skeletal muscles-musculus longissimus thoracis et lumborum, musculus gluteus maximus - were collected, rinsed with PBS, and then stored at $-80{ }^{\circ} \mathrm{C}$ until they were used for biochemical analyses. 


\section{Measurement of Red Blood Cell Indices and Iron Parameters in the Blood Plasma}

RBC indices were measured using ADVIA 2010 analyzer (Siemens, Germany). Iron concentration in the blood plasma and total iron binding capacity (TIBC) were determined by colorimetric measurement of the absorbance of the iron-chromasurol complex at $630 \mathrm{~nm}$ according to the manufacturer's protocol (Biomaxima S.A., Poland). Percent of transferrin saturation (TSAT) was then calculated according to the following formula: TSAT $=$ [plasma iron/TIBC] $\times 100$.

\section{Quantitative Measurement of Non-heme Iron Content in Tissues}

The non-heme iron content of the liver, spleen, kidney, heart, and skeletal muscles (gluteus maximus and longissimus thoracis et lumborum) were determined using colorimetric assay as described previously [25].

\section{Quantitative Measurement of Heme Iron Content in Longissimus Thoracis et Lumborum Muscle}

The heme content of formic acid-solubilized tissues was determined spectrophotometrically at $398 \mathrm{~nm}$ using hemin standards prepared in formic acid and a molar absorption coefficient of $1.5 \times 10^{5} \mathrm{M}^{-1} \mathrm{~cm}^{-1}$ [26].

\section{Real-time Quantitative RT-PCR Analysis of Hepatic Hepcidin mRNA Abundance and Blood Plasma Hepcidin-25 Quantification}

Hepatic hepcidin mRNA levels were measured by a real-time quantitative RT-PCR of cDNA derived from specific transcript in a Light Cycler U96 (Roche Diagnostics, Mannheim, Germany), using the pair of following primers: forward (5'-3') AAGACAGCTCACAGACCTCC, reverse $\left(5^{\prime}-3^{\prime}\right)$ CTACGTCTTGCAGCACATCC. The amplified products were detected using SYBR Green I (Roche Diagnostics) as described previously [22]. For data analysis Light Cycler U96 Software was used. Expression was quantified relative to that of a control transcript encoding the glutathione reductase (GSR) Forward (5'-3') CACAGCTCCTCACATCCTGA, Reverse (5'-3') GGGCAATTCTTCCAGCTGAA.

Measurement of hepcidin-25 level in the blood plasma was performed as described previously for porcine plasma samples [13] by a combination of weak cation exchange chromatography and time-of-flight mass spectrometry (WCX-TOF MS) [27].
Analysis of the Meat Quality and Production Traits

Immediately after slaughter, blood samples were collected as described for 28-day-old piglets. Samples of the duodenum, liver, spleen, kidney, and muscles were collected for further analyses. All carcass parameters were tested according to the methodology applied in Polish Pig Testing Stations as described by Różycki (1996) [28]. The following parameters were registered: average slaughter age, average daily gain (standardized on day 180 of age), slaughter yield, body weight at slaughter, half carcass weight, dressing percentage, meatiness percentage using CGM Sydel apparatus. Meat quality parameters such as loin "eye" area (LEA), backfat thickness (FT), and color/brightness were measured. On hot, hanging right carcass sides using slide caliper backfat thickness at points FTI to FTV were measured Borzuta (1998) [29]. For the LEA measurement, the cut has been made between the last thoracic vertebra and the first lumbar vertebrae and the contour of the muscle was done for planimeter assessment. Color/ brightness of longissimus thoracis et lumborum muscle using MINOLTA CHROMA METERS CR 400. The instrument was calibrated against a standard white plate $(8-\mathrm{mm}$-diameter aperture, $\mathrm{d} / 0$ illumination system, D65 illuminant and a $2^{\circ}$ standard observer angle) determining $\mathrm{L}^{*}$ color component (brightness) parameter was measured. Each measurement was performed 6 times. The mean value was used as the result.

\section{Statistical Analysis}

Results were statistically analyzed with one-way analysis of variance (ANOVA), and Tukey-Kramer post hoc test using GraphPad Prism software (GraphPad, San Diego, CA, USA). The treatment was the fixed effect, and sires were the random effect in the statistical model. $P \leq 0.05$ was considered significant. Data are presented as mean values $\pm \mathrm{SE}$. Experiments were designed in two replicates.

\section{Results and Discussion}

Most iron supplementation procedures in piglets are designed to provide exogenous iron as early as on day 3-6 after birth and thus to prevent the development of IDA during first few weeks of life. Indeed, this period is critical for the maintenance of iron balance because of extremely high iron requirements to sustain hemoglobin synthesis in erythroid cells. Without supplementation, piglets may also show an impaired functioning of the immune system resulting in a greater susceptibility to infectious and parasitic diseases [30]. Most studies dealing with iron supplementation strategies in suckling piglets consider their effectiveness by evaluating $\mathrm{RBC}$ indices and iron status of piglets at weaning (in 4-week-old animals) [8-11] To our knowledge, little attention has been paid to the effect of 
Table 1 Hematological indices of PLW and L990 28- and 180-day-old pigs receiving various iron supplementations

\begin{tabular}{|c|c|c|c|c|c|c|c|c|c|}
\hline \multirow[b]{2}{*}{ Breed $\downarrow$} & \multirow{2}{*}{$\begin{array}{l}\text { Parameter } \\
\text { Age (days) } \rightarrow \\
\text { Supplementation } \downarrow\end{array}$} & \multicolumn{2}{|c|}{$\mathrm{RBC}\left(\times 10^{6} / \mu \mathrm{L}\right)$} & \multicolumn{2}{|l|}{ HGB $(\mathrm{g} / \mathrm{dL})$} & \multicolumn{2}{|l|}{$\mathrm{HCT}(\%)$} & \multicolumn{2}{|l|}{ MCV (fL) } \\
\hline & & 28 & 180 & 28 & 180 & 28 & 180 & 28 & 180 \\
\hline \multirow[t]{2}{*}{ PLW } & Iron dextran & $6.5 \pm 0.11$ & $7.49 \pm 0.18$ & $12.02 \pm 0.50$ & $12.34 \pm 0.38$ & $26.12 \pm 1.37$ & $39.09 \pm 1.24$ & $43.55 \pm 2.22$ & $52.14 \pm 0.85$ \\
\hline & Split & $6.05 \pm 0.49$ & $7.24 \pm 0.41$ & $8.04 \pm 0.58 * *$ & $11.93 \pm 0.46$ & $28.16 \pm 1.96$ & $38.29 \pm 1.67$ & $41.78 \pm 1.82$ & $53.14 \pm 0.98$ \\
\hline \multirow[t]{2}{*}{ L990 } & Iron dextran & $6.35 \pm 0.27$ & $8.48 \pm 0.19^{*}$ & $9.5 \pm 0.65^{*}$ & $13.77 \pm 0.29 *$ & $31.21 \pm 1.96^{*}$ & $43.79 \pm 1.11 *$ & $43.80 \pm 2.23$ & $53.00 \pm 0.78$ \\
\hline & Split & $5.90 \pm 0.37$ & $8.31 \pm 0.18^{*}$ & $8.60 \pm 0.56^{* *}$ & $13.21 \pm 0.19 *$ & $28.90 \pm 1.66$ & $43.56 \pm 0.60 *$ & $42.10 \pm 1.73$ & $52.43 \pm 0.71$ \\
\hline
\end{tabular}

Values are expressed as the means $\pm \mathrm{SE}$. RBC indices were determined for seven pigs of each treatment group. $R B C$ red blood cell count, $H G B$ hemoglobin level, $H C T$ hematocrit, $M C V$ mean corpuscular volume, $R D W$ red blood cell distribution width, $M C H$ mean corpuscular hemoglobin. $* P<0.05$, significant differences between PLW and L990 pigs within a given supplementation group. $* * P<0.05$, significant differences between pigs receiving split and routine supplementation within a given breed

pre-weaning iron supplementation on the status of this microelement in pigs during the post-weaning period [31]. Meanwhile, it seems that in a long-term perspective iron repletion in pigs is important not only for their health but also for their growth performance and nutritional value of pork.

In the present study, we first aimed at evaluating the impact of an early split iron supplementation in piglets on both RBC and iron plasma parameters at the end of fattening, i.e., in approximately 180-day-old PLW and L990 pigs (Table 1 and Fig. 1). We hypothesized that although piglets receiving a combined supplementation are not fully replete with iron at weaning [22, 32 and this study-Table 1], during the postweaning period they can accommodate iron absorption to sustain growth performance and iron content in tissues. Accordingly, it has been demonstrated that a few months pigs highly express apical (divalent metal transporter 1) and basolateral (ferroportin) iron transporters not only on duodenal enterocytes but also on colonocytes [33]. Concentration of hemoglobin in 28-day-old piglets receiving split supplementation indicates that depending on various cut-off values, these animals are slightly below [34] or above [35] the border line of anemia (Table 1). It is noteworthy that blood plasma iron parameters indicate slight iron deficiency but only in PLW piglets (Fig. 1a-c). In contrast, piglets supplemented with high amount of FeDex definitely exhibit a non-anemic phenotype (Table 1). In our previous study we demonstrated that 28-dayold piglets supplemented exclusively with a single, low dose of FeDex (i.e., a parenteral component of split supplementation used in this study) are definitely iron deficient and show clear symptoms of IDA [13]. Assuming that IDA in these animals at weaning is far advanced, we considered them not suitable for investigating long-term effect of preweaning iron
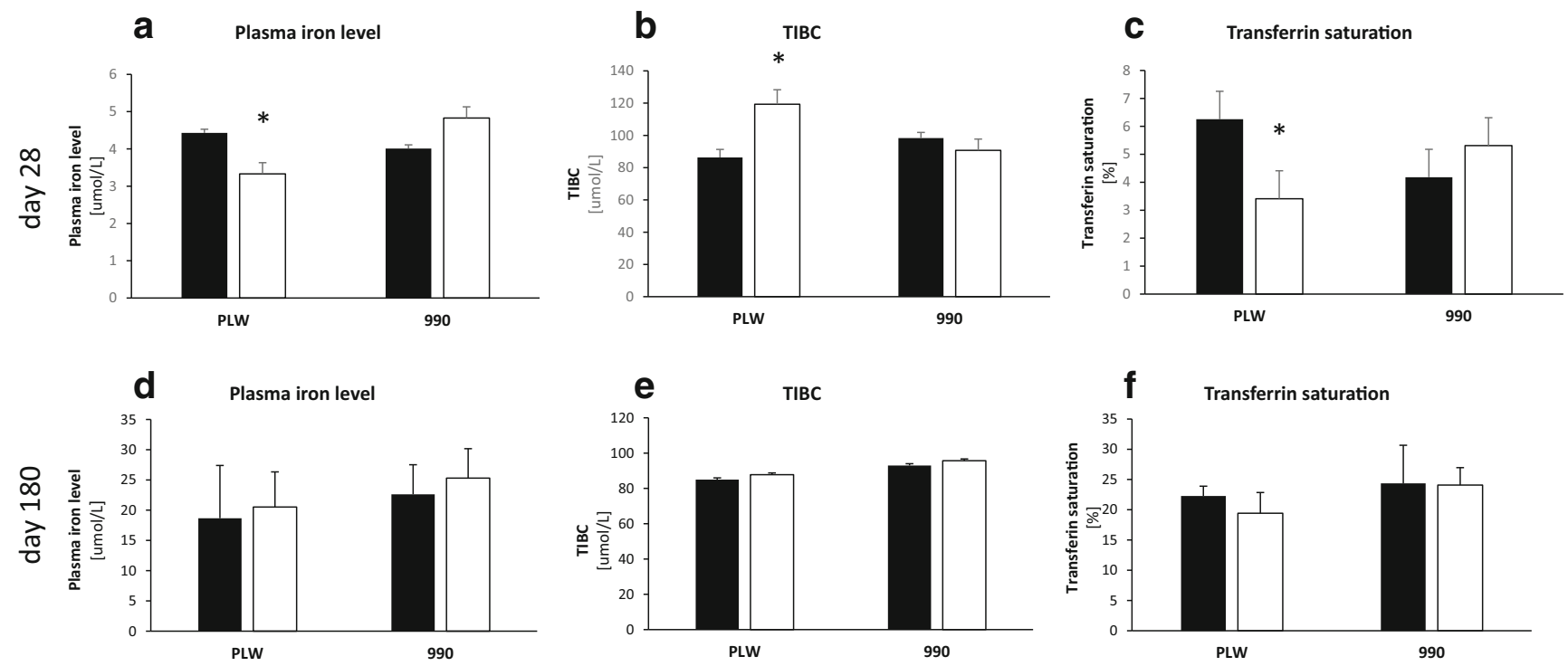

Fig. 1 Iron status in the blood plasma of PLW and L990 in 28-day-old and $\sim 180$-day-old pigs receiving various iron supplementations. 28-dayold: (a) blood plasma iron; (b) total iron binding capacity (TIBC); (c) transferrin saturation; $\sim 180$-day-old: (d) blood plasma iron; (e) total iron binding capacity (TIBC); (f) transferrin saturation. Values are expressed

as the means \pm SE for plasma samples obtained from 7 pigs from each experimental group. Solid bars, piglets supplemented with high-dose FeDex; open bars, piglets receiving split FeDex/hemoglobin supplementation 


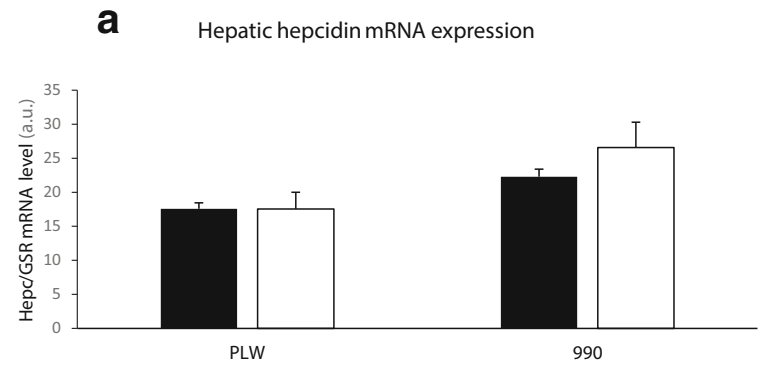

Fig. 2 Hepatic hepcidin mRNA expression and plasma hepcidin concentrations of PLW and L990 180-day-old pigs receiving various iron supplementations: (a) hepatic hepcidin mRNA expression; (b)

supplementation. Interestingly, at weaning piglets from two analyzed breeds within a given supplementation group show very similar RBC status, except higher level of HGB in PLW animals (Table 1). In contrast, at the end of fattening, L990 pigs display significantly higher values of the majority of $\mathrm{RBC}$ indices such as RBC count, hemoglobin concentration, and hematocrit values compared with PLW animals (Table 1). Most importantly, RBC parameters in finishing animals of both breeds receiving either routine or split supplementation do not differ significantly (Table 1). Similarly, iron status in the blood plasma of PLW and L990 adult pigs is comparable regardless supplementation procedure (Fig. 1d-f). Consequently, hepcidin mRNA expression as well as blood plasma concentration of hepcidin- 25 in adult pigs shows no b

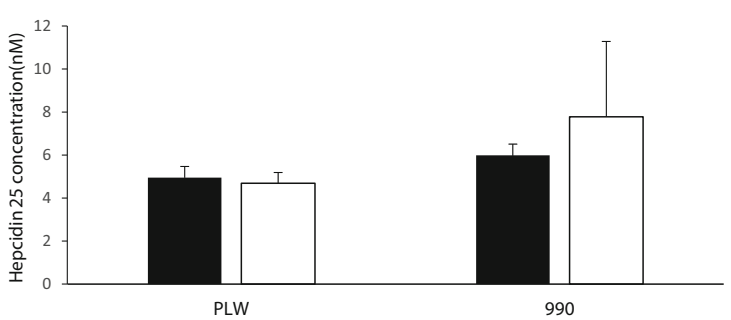

plasma hepcidin concentrations. Solid bars, piglets supplemented with high-dose FeDex; open bars, piglets receiving split FeDex/hemoglobin supplementation

statistically significant differences neither between pig breeds nor between supplementation groups (Fig. 2). These results clearly indicate that piglets receiving split supplementation and showing slightly anemic RBC status at weaning, during post-weaning period are able to improve RBC parameters, stabilize them within the physiological range [32, 36-38], and correct their iron status. This recovery attests a very efficient process of iron absorption from high iron-containing diets given to growing and finishing pigs (see the "Materials and Methods" section). Appropriate values of RBC indices are not always associated with iron repletion in tissues because erythroid compartment is on the first line of iron demand consuming major part of iron supply in the body [39]. Therefore, we measured iron content in tissues such as the
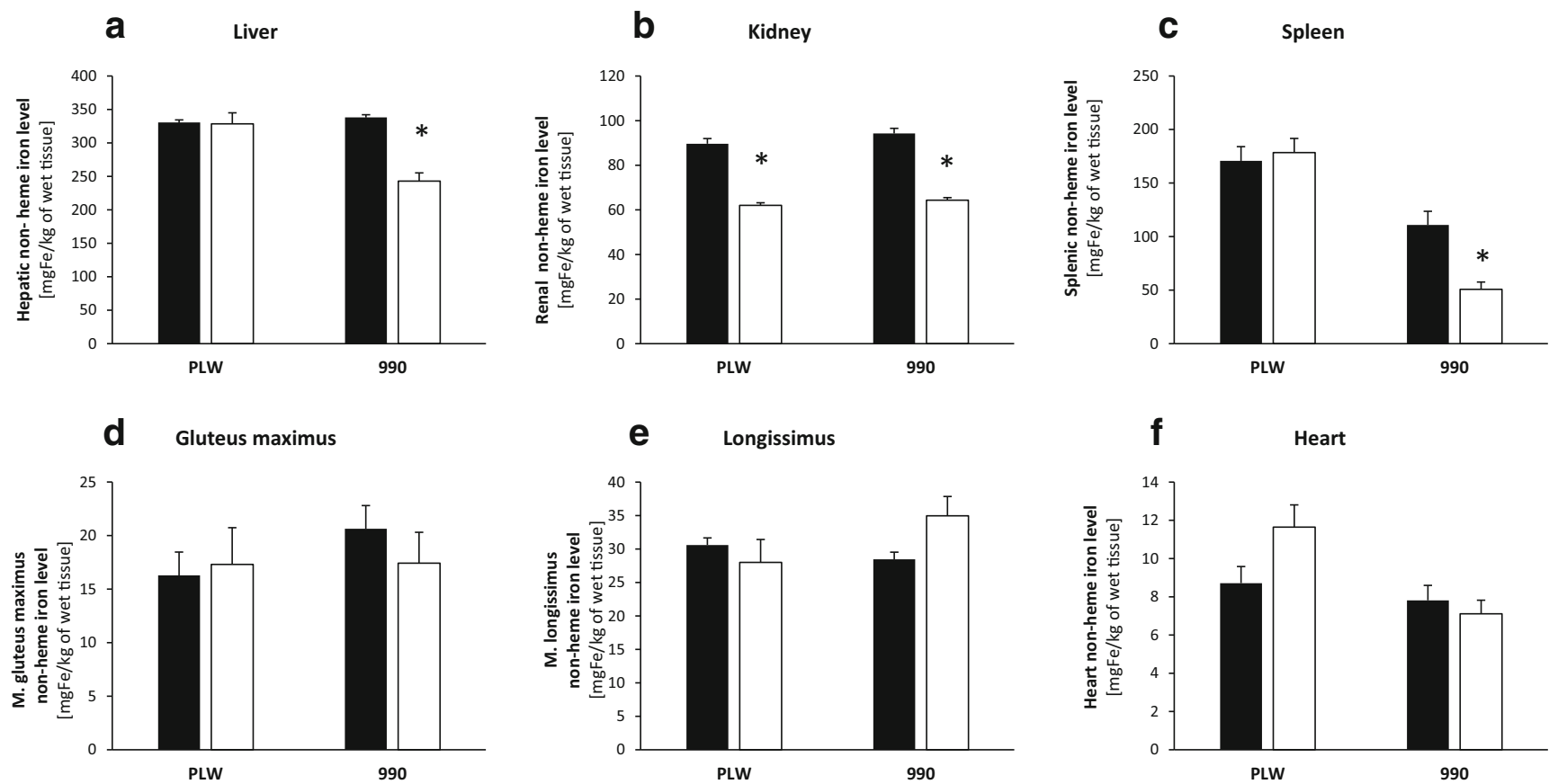

Fig. 3 Comparison of the tissular non-heme iron content in PLW and L990 180-day-old pigs receiving various iron supplementations. Tissue non-heme iron content was measured in following tissues: (a) liver; (b) kidney; (c) spleen; (d) gluteus maximus muscle; (e) longissimus thoracis et lumborum muscle; and (f) heart. Values are expressed as the

means \pm SE for tissue samples obtained from pigs of each group $(N=7)$. $* P<0.05$, significant differences between pigs receiving split and routine supplementation within a given breed. Solid bars, piglets supplemented with high-dose FeDex; open bars, piglets receiving split FeDex/ hemoglobin supplementation 

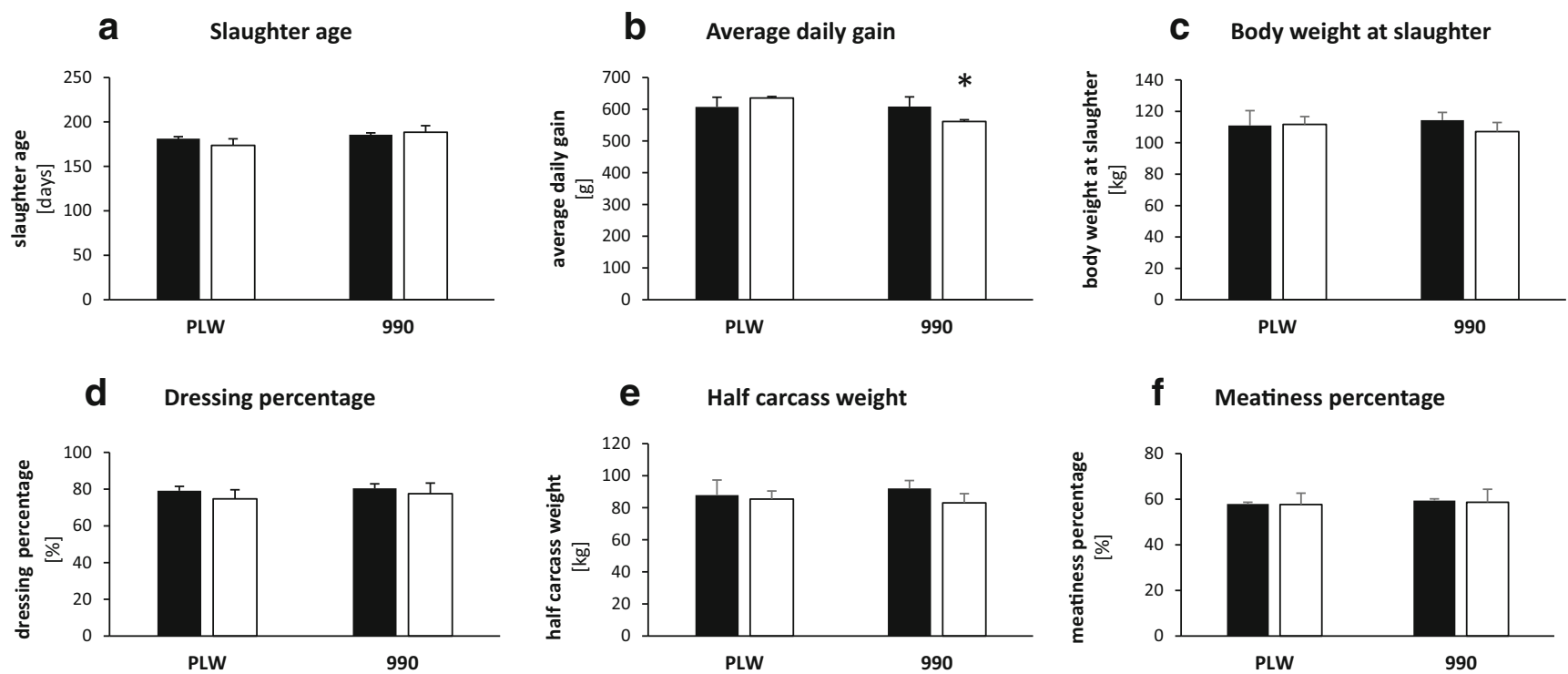

Fig. 4 Growth performance and carcass parameters in PLW and L990 180-day-old pigs receiving various iron supplementations: (a) slaughter age; (b) average daily gain; (c) body weight at slaughter; (d) dressing percentage; (e) half carcass weight; and (f) meatiness percentage. Values are expressed as the means $\pm \mathrm{SE}$ for pigs of each group $(N=7)$. $* P<0.05$,

significant differences between pigs receiving split and routine supplementation within a given breed. Solid bars, piglets supplemented with high-dose FeDex; open bars, piglets receiving split FeDex/ hemoglobin supplementation

liver, spleen, kidney, skeletal muscles, and heart and found statistically significant differences between animals from two supplementation groups in the kidney (lower iron content in pigs receiving split supplementation in both PLW and L990 breeds), in the spleen (lower iron content in L990 pigs supplemented with FeDex and hemoglobin), and in the liver (lower iron content in L990 pigs supplemented with hemoglobin) (Fig. 3). Interestingly, splenic iron content was significantly lower in L990 than in PLW pigs regardless the

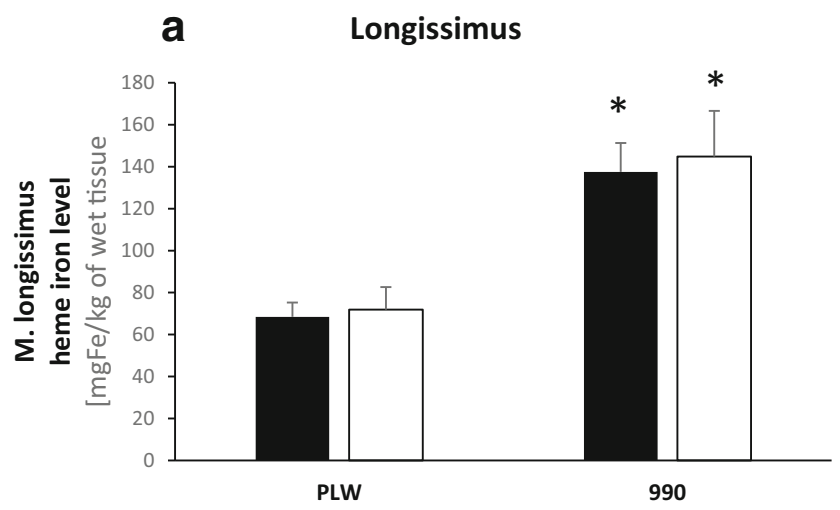

Fig. 5 Comparison of the longissimus thoracis et lumborum muscle heme iron content in PLW and L990 180-day-old pigs receiving various iron supplementations. Musculoskeletal heme iron content was measured in (a) longissimus thoracis et lumborum muscle. Values are expressed as the means $\pm \mathrm{SE}$ for pigs of each group $(N=7) . * P<0.05$, significant differences between PLW and L990 pigs within a given supplementation group. Solid bars, piglets supplemented with high-dose FeDex; open bars, piglets receiving split FeDex/hemoglobin supplementation supplementation and we hypothesized that this is connected with overall higher iron demand for erythropoiesis in L990 pigs showing higher RBC status compared with PLW animals (Table 1). Hemoglobin contained in erythrocytes accounts for the largest pool of heme and, consequently, iron. Bone marrow erythroblasts acquire more than $80 \%$ of plasma iron [39]. Therefore, higher RBC status of L990 piglets is associated with higher iron demand to maintain adequate erythropoiesis in these animals. According to Michalska et al. 2006 [40], pigs of L990 breed (a terminal sire breed) are also characterized by faster growth rate than animals belonging to PLW breed (maternal breed) and it could be an additional factor of greater iron requirements of these animals.

Considering that pork meat is a valuable source of iron for consumers, it is noteworthy that split supplementation did not result in lower iron content of skeletal muscles such as musculus longissimus thoracis et lumborum and musculus gluteus maximus in PLW and L990 pigs compared with commonly used high FeDex supplementation (Figs. 3d, e and 5). The slaughter age of pigs was similar among treatments and breeds (Fig. 4a). Comparing to classical supplementation with high dose of FeDex, split FeDex/hemoglobin procedure supported similar average daily gain (Fig. 4b) and final body weight of PLW pigs (Fig. 4c). However, in L990 pigs receiving split supplementation, average daily gain was significantly lower $(P<0.05)$ suggesting that this supplementation does not fully support the fast growth of these animals [40-42]. Apparently, basal iron content in diets for grower-finisher pigs is largely sufficient to compensate for moderate deficiency at weaning and to sustain both normal growth and slaughter 
Table 2 Backfat thickness from 5 measurements and selected meat quality parameters in PLW and L990 180-day-old pigs receiving various iron supplementations

\begin{tabular}{llllllllll}
\hline Breed $\downarrow$ & $\begin{array}{l}\text { Parameter } \rightarrow \\
\text { Supplementation } \downarrow\end{array}$ & $\begin{array}{l}\text { FT1 } \\
(\mathrm{cm})\end{array}$ & $\begin{array}{l}\text { FT2 } \\
(\mathrm{cm})\end{array}$ & $\begin{array}{l}\text { FT3 } \\
(\mathrm{cm})\end{array}$ & $\begin{array}{l}\text { FT4 } \\
(\mathrm{cm})\end{array}$ & $\begin{array}{l}\text { FT5 } \\
(\mathrm{cm})\end{array}$ & $\begin{array}{l}\text { FTav } \\
(\mathrm{cm})\end{array}$ & $\begin{array}{l}\text { LEA } \\
\left(\mathrm{cm}^{2}\right)\end{array}$ & $\begin{array}{l}\text { Color brightness }(\%) \\
\text { PLW }\end{array}$ \\
& Iron dextran & $3.09 \pm 0.42$ & $1.88 \pm 0.19$ & $2.36 \pm 0.38$ & $1.38 \pm 0.12$ & $1.97 \pm 0.03$ & 2.16 & $57.60 \pm 2.27$ & $53.48 \pm 1.21$ \\
& Split & $2.87 \pm 0.38$ & $1.70 \pm 1.03$ & $2.16 \pm 0.12$ & $1.33 \pm 0.11$ & $2.03 \pm 0.07$ & 2.02 & $53.14 \pm 2.19$ & $54.68 \pm 1.42$ \\
\multirow{2}{*}{ L990 } & Iron dextran & $3.29 \pm 0.19$ & $2.04 \pm 0.53$ & $2.49 \pm 0.12$ & $1.47 \pm 0.09$ & $2.23 \pm 0.16$ & 2.32 & $56.79 \pm 2.07$ & $55.40 \pm 1.17$ \\
& Split & $3.21 \pm 0.20$ & $1.93 \pm 0.56$ & $2.45 \pm 0.19$ & $1.30 \pm 0.08$ & $1.83 \pm 0.12$ & 2.14 & $55.73 \pm 1.96$ & $55.68 \pm 2.18$ \\
\hline
\end{tabular}

Animal quality traits were measured as described in the "Materials and Methods" section. Values are expressed as the means \pm SE for pigs of each group $(N=7)$

performance in PLW but not in L990. It is highly probable that this phenomenon is associated with the high iron demand of this breed for erythropoiesis. Red blood cell indices in L990 piglets/pigs are significantly higher compared with PLW animals (Table 1). Apart from high erythroid iron acquisition, greater need for iron in L990 piglets may result from the use of large amounts of this microelement to sustain heme and myoglobin synthesis in muscle tissue (see Fig. 5 heme iron content). Iron transport to the bone marrow is dependent on endocytosis of diferric transferrin ( $\mathrm{Tf}-\mathrm{Fe}_{2}$ ) via the transferrin receptor 1 (TFR1) abundantly expressed on erythroid cell [39]. The preferential movement of iron to the bone marrow (at the expense of other tissues) may result in a lower content of this biometal in the liver and kidney (Fig. 3) and may be also responsible for a slight growth retardation (Fig. 4).

Importantly, addition of iron to post-weaning basal diets increasing its content above NRC requirements [43, 44] has been shown dispensable for the improvement of growth performance of pigs, carcass characteristics, and pork quality [21, 45]. However, in contrast to elemental iron (ferrous sulfate), supplemental heme iron given to pigs starting from week 5 after birth favored greater body weight of animals on week 20 after birth suggesting better bioavailability of heme iron than that of elemental iron [46]. It is well known that meat color is a relevant factor that affects meat quality [47]. Meat color is mainly determined by myoglobin, which is the dominant pigment in the skeletal muscle [48]. Interestingly, supplemental heme has been also shown to increase the redness and myoglobin level (which is the main source of heme iron in skeletal muscles) of longissimus thoracis et lumborum muscle of 2month-old piglets when compared with ferrous sulfate as elemental iron source [46].

According to Blicharski et al. (2014) [47] and Borzuta and Lisiak (2016) [49] and as shown in this study (Fig. 4), carcass parameters of PLW and L990 pigs traditionally supplemented with FeDex do not differ significantly. Here, in addition, we show that main meat quality parameters such as loin "eye" area (LEA), color/brightness of meat, backfat thickness, and heme iron level of longissimus thoracis et lumborum in pigs of both breeds receiving split FeDex/heme supplementation are very similar to those measured in at slaughter in animals traditionally supplemented with high amount of FeDex (Table 2 and Fig. 5). Therefore, it is tempting to propose that split supplementation could be recommended for use on a larger scale in pig production.

\section{Conclusion}

Summing up, our data clearly demonstrate that the combine supplementation of piglets during pre-weaning period with a small amount of intramuscularly injected FeDex and orally given hemoglobin (up to day 45 after birth) is a procedure that warrants further normal growth performance of animals up to slaughter as well as assures high quality of pork. Even though this split supplementation does not fully rebalance RBC and iron status of piglets at weaning, it paves the way for normal pig development under standard iron feeding conditions (from birth until the weaning and at the end of fattening). We postulate that exclusive oral supplementation of suckling piglets with highly available heme iron supplements (even without small amount of intramuscularly injected FeDex) is worth considering for pig breeders. Despite its poorer efficiency in rectifying iron status at weaning compared with classical supplementation with FeDex. We believe that elimination of the supplementation of piglets with FeDex injected intramuscularly will allow to avoid several inconveniences of this routine procedure such as invasiveness, pain, and high labor consumption.

Funding Information This work was supported by The National Science Centre, Poland, grant no. 2017/25/B/NZ9/01707 and KNOW- Leading National Research Centre, Scientific Consortium "Healthy Animal - Safe Food”, grant no. KNOW/IGHZ/RMK/PhD/2016/01.

Compliance with Ethical Standards The experimental procedures used in this study were in compliance with the EU guidelines for the care and handling of research animals (EU Directive 2010/63/EU for animal experiments). According to Polish legislation, tests on animals using feed additives and supplements (including iron supplements such as $\mathrm{FeSO}_{4}$, hemoglobin, dried erythrocytes, plasma, blood) are not considered research procedures and therefore do not interfere with animal welfare. Therefore, ethical permission is not required. 
Conflict of Interest The authors declare that they have no conflict of interest.

Open Access This article is distributed under the terms of the Creative Commons Attribution 4.0 International License (http:// creativecommons.org/licenses/by/4.0/), which permits unrestricted use, distribution, and reproduction in any medium, provided you give appropriate credit to the original author(s) and the source, provide a link to the Creative Commons license, and indicate if changes were made.

\section{References}

1. Szudzik M, Starzyński RR, Jończy A, Mazgaj R, Lenartowicz M, Lipiński P (2018) Iron supplementation in suckling piglets: an ostensibly easy therapy of neonatal iron deficiency anemia. Pharmaceuticals (Basel) 11(4):128

2. Svoboda M, Drabek J (2005) Iron deficiency in suckling piglets: etiology, clinical aspects and diagnosis. Folia Veterinaria 49:104 111

3. Svoboda M, Pískova K (2018) Oral iron administration in suckling piglets - a review. Acta Vet Brno 87:77-83

4. Lipiński P, Styś A, Starzyński RR (2013) Molecular insights into the regulation of iron metabolism during the prenatal and early postnatal periods. Cell Mol Life Sci 70(1):23-38

5. Pond WG, Lowrey S, Maner JH, Loosli JK (1961) Parenteral iron administration to sows during gestation or lactation. J Anim Sci 20(4):747-750

6. Chaney CH, Barnhart CE (1963) Effect if iron supplementation of sow rations on the prevention of baby pig anemia. J Nutr 81:187192

7. Csapo JE (1996) Proteins, fat vitamins and mineral concentration in porcine colostrum and milk from parturition to 60 days. Int Dairy $\mathrm{J}$ 6:881-902

8. Lipiński P, Starzyński RR, Canonne-Hergaux F, Tudek B, Oliński $R$, Kowalczyk P et al (2010) Benefits and risks of iron supplementation in anemic neonatal pigs. Am J Pathol 177:1233-1243

9. Egeli AK, Framstad T (1999) An evaluation of iron-dextran supplementation in piglets administered by injection on the first, third or fourth day after birth. Res Vet Sci 66(3):179-184

10. Kleinbeck SN, McGlone JJ (1999) Intensive indoor versus outdoor swine production systems: genotype and supplemental iron effects on blood hemoglobin and selected immune measures in young pigs. J Anim Sci 77(9):2384-2390

11. Rincker MJ, Clarke SL, Eisenstein RS, Link JE, Hill GM (2005) Effects of iron supplementation on binding activity of iron regulatory proteins and the subsequent effect on growth performance and indices of hematological and mineral status of young pigs. J Anim Sci 83:2137-2145

12. Staroń R, Van Swelm RP, Lipiński P, Gajowiak A, Lenartowicz M, Bednarz A et al (2015) Urinary hepcidin levels in iron-deficient and iron-supplemented piglets correlate with hepcidin hepatic mRNA and serum levels and with body iron status. PLoS One 10(8): e0136695

13. Starzyński RR, Laarakkers CM, Tjalsma H, Swinkels DW, Pieszka M, Styś A et al (2013) Iron supplementation in suckling piglets: how to correct iron deficiency anemia without affecting plasma hepcidin levels. PLoS One 8(5):e64022

14. Ganz T, Nemeth E (2011) Hepcidin and disorders of iron metabolism. Annu Rev Med 62:347-360

15. Nemeth E, Ganz T (2006) Regulation of iron metabolism by hepcidin. Annu Rev Nutr 26:323-342

16. Gonzalez-Rosendo G, Polo J, Rodriguez-Jerez JJ, Puga-Diaz R, Reyes-Navarrete EG, Quintero-Gutierrez AG (2010) Bioavailability of a heme-iron concentrate product added to chocolate biscuit filling in adolescent girls living in a rural area of Mexico. J Food Sci 75:73-78

17. Young MF, Griffin I, Pressman E, McIntyre AW, Cooper E, McNanley T, Harris ZL, Westerman M, O’Brien KO (2010) Utilization of iron from an animal-based iron source is greater than that of ferrous sulfate in pregnant and nonpregnant women. J Nutr 140:2162-2166

18. Young MF, Griffin I, Pressman E, McIntyre AW, Cooper E, McNanley T, Harris ZL, Westerman M, O’Brien KO (2012) Maternal hepcidin is associated with placental transfer of iron derived from dietary heme and nonheme sources. J Nutr 142:33-39

19. Weintraub LR, Weinstein MB, Huser HJ, Rafal S (1968) Absorption of hemoglobin iron: the role of a heme-splitting substance in the intestinal mucosa. J Clin Investig 47(3):531-539

20. Antileo R, Figueroa J, Valenzuela C (2016) Characterization of a novel encapsulated oral iron supplement to prevent iron deficiency anemia in neonatal piglets. J Anim Sci 94:157-160

21. Quintero-Gutierrez AG, Gonzalez-Rosendo G, Sanchez-Munoz J, Polo-Pozo J, Rodriguez-Jerez JJ (2008) Bioavailability of heme iron in biscuit filling using piglets as an animal model for humans. Int J Biol Sci 4:58

22. Staroń R, Lipiński P, Lenartowicz M, Bednarz A, Gajowiak A, Smuda E, Krzeptowski W, Pieszka M, Korolonek T, Hamza I, Swinkels DW, Van Swelm RPL, Starzyński RR (2017) Dietary hemoglobin rescues young piglets from severe iron deficiency anemia: duodenal expression profile of genes involved in heme iron absorption. PLoS One 12(7):e0181117

23. Cebulska A, Kapelański W, Frątczak K (2012) Breeding and production of pigs in Poland. Research in Pig Breeding 6(1):13-16

24. Borzuta K, Strzelecki J, Dziadek K, Grzeskowiak E, Lisiak D, Janiszewski P (2008) Analiza porównawcza wartości rzeźnej i Jakości mięsa świń Hybrydyzowanych linii Pen-ar-lan oraz 990. Roczniki Naukowe Zootechniki 35(1):63-73

25. Torrance JD, Bothwell TH (1980) Tissue iron stores. Methods in Hematology 1:90-115

26. Motterlini R, Foresti R, Vandegriff K, Intaglietta M, Winslow RM (1995) Oxidative-stress response in vascular endothelial cells exposed to acellular hemoglobin solutions. Am J Physiol 269(2):648655

27. Laarakkers CMM, Wiegerinck ET, Klaver S, Kolodziejczyk M, Gille H, Hohlbaum AH, Tjalsma H, Swinkels DW (2013) Improved mass spectrometry assay for plasma hepcidin: detection and characterization of a novel hepcidin isoform. PLoS One 8: e75518

28. Różycki M (1996) Zasady postępowania przy ocenie świń w Stacjach Kontroli Użytkowości Rzeźnej Trzody Chlewnej (Principles of pig evaluation in polish pig testing stations) $\mathrm{W}$ : Stan hodowli i wyniki oceny świń (In: Current situation in breeding and evaluation of pigs). Instytut Zootechniki Kraków (National Research Institute for Animal Production, Cracow) 14:69-82

29. Borzuta K (1998) Badania nad przydatnością różnych metod szacowania mięsności do klasyfikacji tusz wieprzowych w systemie EUROP (Studies on usefulness of different methods of meatines evaluation for the classification of porcine carcasses in the EUROP system). In Polish, summary in English. Roczniki Instytutu Przemysłu Mięsnego i Tłuszczowego 35(2):1-83

30. Pedersen S, Saeed I, Friis H, Michaelsen K (2001) Effect of iron deficiency on Trichuris suis and 2 Ascaris suum infections in pigs. Parasitology 122(5):589-598

31. Perri AM, Friendship RM, Harding JSC et al (2016) An investigation of iron deficiency and anemia in piglets and the effect of iron status at weaning on post-weaning performance. Journal of Swine Health and Production 24(1):10-20

32. Thorn CE (2010) Hematology of the pig, In: Feldman BF, Zink1 JG and Jain NC, Eds., Schalm's veterinary hematology, 6th Edition. Lippincott Williams \& Wilkins, Philadelphia 109:843-850 
33. Blachier F, Vaugelade P, Robert V, Kibangou B, Canonne-Hergaux F, Delpal S, Bureau F, Blottière H, Bouglé D (2007) Comparative capacities of the pig colon and duodenum for luminal iron absorption. Can J Physiol Pharmacol 85(2):185-192

34. Bhattarai S, Nielsen JP (2015) Early indicators of iron deficiency in large piglets at weaning. Journal of Swine Health and Production 23:10-17

35. Egeli AK, Framstad T, Morberg H (1998) Clinical biochemistry, haematology and body weight in piglets. Acta Vet Scand 39:381393

36. Friendship RM, Lumsden JH, McMillan I, Wilson MR (1984) Hematology and biochemistry reference values for Ontario swine. Canadian Journal of Rural Medicine 48:390-393

37. Perri AM, O'Sullivan TL, Harding JCS, Wood RD, Friendship RM (2017) Hematology and biochemistry reference intervals for Ontario commercial nursing pigs close to the time of weaning. The Canadian Veterinary Journal 58(4):371-376

38. Ventrella D, Dondi F, Barone F, Serafini F, Elmi A, Giunti M, Romagnoli N, Forni M, and Bacci M.L (2016) The biomedical piglet: establishing reference intervals for haematology and clinical chemistry parameters of two age groups with and without iron supplementation. BMC Vet Res 13:23

39. Muckenthaler M, Rivella S, Hentze MW, Galy B (2017) A red carpet for iron metabolism. Cell 168(3):344-361

40. Michalska G, Nowachowicz J, Bucek T, Wasilewski P.D (2006) Wyniki oceny przyżyciowej knurków mieszańców linii 990 i rasy Pietrain różniących się tempem wzrostu. Zeszyty Naukowe nr 248 Zootechnika 36:93-98

41. Michalska G, Nowachowicz J, Chojnacki Z, Bucek T, Wasilewski P.D. (2004). Analysis of the results of performance tested young crossbred boars. Ann Anim Sci 2:49-53
42. Różycki M, Dziadek K (2012) Utworzenie i wykorzystanie linii świń 990 do produkcji tuczników. Wiadomości Zootechniczne 3: $27-36$

43. (NRC) (1998) Nutrient requirements of swine. National Research Council (10th ed.). The National Academies Press, Washington, DC

44. (NRC) (2012) Nutrient requirements of swine National Research Council, 11th edn. The National Academies Press, Washington, DC

45. Apple JK, Wallis-Phelps WA, Maxwell CV, Rakes LK, Sawyer JT, Hutchison S, Fakle TM (2006) Effect of supplemental iron on finishing swine performance, carcass characteristics, and pork quality during retail display. J Anim Sci 85(3):737-745

46. Zhuo Z, Yu X, Li S, Fang S, Feng J (2018) Heme and non-heme Iron on growth performances, blood parameters, tissue mineral concentration and intestinal morphology of weanling pigs. Biol Trace Elem Res 187(2):411-417

47. Blicharski T, Ptak J, Hammermeister A, Snopkiewicz M (2014) 2003 do 2014 - Wyniki oceny trzody chlewnej. Wyd PZHiPTCh „POLSUS"

48. Olsson V, Pickova J (2005) The influence of production systems on meat quality, with emphasis on pork. Ambio 34(4):338-343

49. Borzuta K, Lisiak D (2016) Ewolucja wartości rzeźnej trzody chlewnej w Polsce w ostatnim sześćdziesięcioleciu. Przegląd hodowlany 4(2016):1-5

Publisher's Note Springer Nature remains neutral with regard to jurisdictional claims in published maps and institutional affiliations. 